DOI https://doi.org/10.18551/rjoas.2017-08.04

\title{
FINANCIAL REPORTING AND CORPORATE TAX AGGRESSIVENESS: IMPACT ON FIRM VALUE
}

\author{
Agusti Rosalita Rachma \\ Faculty of Administrative Science, University of Brawijaya, Indonesia \\ E-mail: rosalitarachma@ub.ac.id
}

\begin{abstract}
This research aims to study the market response to the aggressiveness of financial reporting and tax reporting conducted by the company. Investor's response is reflected in the market value of the company's stock. This study is an explanatory research using quantitative approach. Research's sample is a manufacturing company listed on the Indonesian stock exchanges from 2005 to 2015. The data were analyzed using multiple regression analysis. The data show that majority of sample companies' fall into the category of middle tax aggressiveness. Research's findings are both aggressive financial reporting and tax aggressiveness has a negative relationship with the market value of the company. However, only aggressive financial reporting that has a significant influence on the firm value. Based on these results it is concluded that tax aggressiveness does not directly affect the market in making decisions to assess the company's stock.
\end{abstract}

\section{KEY WORDS}

Financial reporting, aggressiveness, tax aggressiveness, firm, value.

Tax reform in Indonesia brought a change from the enactment of the official assessment system to self-assessment system. The system changes aimed at several things such as optimizing revenue, raising taxpayers' awareness and compliance, and administrative efficiency (Sarunan, 2015). Implementation Self-assessment system in Indonesia brings various impacts both positive and negative. The positive impact of the implementation of the system is the taxpayer has full trust in performing tax obligations. However, in addition to the positive impact the implementation of the system also has a negative impact that raises the possibility of doing tax fraud (Wahyuni, 2011).

Tax non-compliance is a condition in which taxpayers are reluctant to fulfill their obligations to the government to pay taxes (Utomo, 2012). Factors causing non-compliance of taxpayers among others arise because of agency relationships (Desai and Dharmapala, 2009). Shareholders who have interests in the profit want maximum profit so that the value of the stock is also maximized in accordance with the purpose of investment. While management has a responsibility to run the company in accordance with the interests of all stakeholders including shareholders and government.

Different interests between stakeholders encourage management to engineer financial statements. With regard to taxation interests, various ways of reducing tax liabilities include reducing recorded profits, inflating tax deductions and tax shelters in different jurisdictions due to different tax rates (Desai and Dharmapala, 2009). Therefore the tax obligation encourages the company to conduct tax aggressiveness.

Engineering financial statements with the aim of reducing taxation obligations motivate companies to perform aggressiveness of financial statements. The aggressiveness of such financial statements involves the management of earnings to reduce recorded profit. Such earnings engineering activity occurs because management has the motivation to record high profits as evidence of performance and performance. High earnings will attract investors to buy the company's shares so that the value of the company will also increase.

The company according to its objectives will seek to maximize the value of the company. The value of the company is determined by the shareholders. Shareholders will rate the company higher by the ability to generate good taxes. Therefore, management will try to generate high profits. Management in the business of generating high profits must also 
meet the interests of other stakeholders, namely the government. The government has an interest in the company of taxes. Taxes in accounting are a deduction of profits. Therefore, management will make efforts to manage taxes in order to maximize profits and increase the value of the company. Tax aggressiveness has an impact on corporate value (Utomo, 2012; Crocker and Slemrod, 2004; Frank et al, 2009; Desai and Dharmapala, 2009).

\section{LITERATURE REVIEW}

Agency Theory. Jensen \& Meckling popularized agency theory or agency theory in 1976. This theory is based on the relationship between the principal and the agent. Managers are empowered by the owners of the company, ie shareholders, to make decisions, and this creates potential conflicts over interests called agency theory (Brigham \& Houston, 2001: 22). According to Jensen and Meckling (1976), agency relationships arise when a person or more (principal) employs another person (agent) to do a job in the interests of the principal by delegating decision-making authority to the agent. Each party associated with the company has different interests, therefore the company is a place for meeting the interests terxebut. The company brings together the agency relationship between the company owner and management. In addition, the agency relationship in the company also involves the relationship between the creditor and the company owner.

Managers are appointed by shareholders (owners) to run the company, in order to achieve company goals, that is maximizing the value of the company or commonly described as shareholder wealth. In addition to achieving these objectives, management has a tendency to take action that is inconsistent with the aim of increasing shareholder wealth. Management often has interests that are different from those objectives so that it may create a conflict of interest between shareholders and management or the so-called agency problem.

Jensen \& Meckling (1976) mentions that agency problems will occur when company managers have less than $100 \%$ of the company's shares. If the company is a sole proprietorship, where the owner and manager, then the manager / owner will run the company to maximize its welfare. But for a public company whose shares are owned by outsiders other than managers (public) then the conflict will arise. Management will strive to meet its own interests rather than maximizing corporate value. Management tends to spend consumptive and unproductive expenditures to improve their welfare, such as an increase in salaries or bonuses.

Agency problems will arise when the company generates great free cash flow. Free cash flow is a net cash flow that can not be reinvested because there is no profitable investment opportunity (Sartono: 2001,14). Free cash flow will cause agency problems because the company owner (shareholder) wants the cash to be distributed to the shareholders, but the management wants the cash not to be shared so that it remains in management control. Another cause of conflict between manager and owner is regarding funding decisions. Husnan (1996: 277) disclose that the company's funding decision concerns decisions about the shape and composition of funding to be used by the company. Funding functions should be done efficiently. According Riyanto (1995: 5) financial managers should make sure the company can obtain the necessary funds with minimal cost and the most favorable terms.

According to Brigham \& Houston (2001: 23) there are several mechanisms that can be done to motivate management to work in the interests of shareholders. The mechanisms are (1) Managerial compensation, this compensation is done to attract and retain a capable manager and to direct the manager's actions to approximate the shareholder's interest in maximizing stock prices. (2) The threat of hostile takeover, hostile takeover is a condition of the company forcibly taken over by another party that occurs because the company's shares are rated too low due to poor management. In a forced takeover, the management of the foreclosed company will be dismissed. (3) The threat of dismissal for management that does not work in accordance with shareholder expectations. (4) Direct shareholder intervention. 
Shareholders have influence over the operations of the company and may use it, among others, to provide advice on how the company should be run.

Agency problems may occur also between the creditor and the shareholder. Both the creditor and the investor (shareholder) have a claim on the company's assets, but the creditor has a claim in advance of the investor. The lender provides loans to the company with a fixed income of interest and loan repayment. Regardless of the amount of profits earned by the company, the income received by the creditor is fixed. Instead, investors have different forms of return with creditors. Investors earn income from the excess on the obligations to be paid to the creditor. This is related to the nature of the investor as a residual claim. Thus, the investor's right will be granted after the liability to the creditor is paid.

If the company's earnings are less than the liabilities to the creditor then all profits will be used to pay the liability, while the investor does not get a share of the profits. The investor will receive an income if there is an excess of the liabilities to be paid to the creditor. This causes investors to encourage management to invest with high risk. High-risk projects are expected to generate high profits too, so shareholders' share is also getting bigger. If this high-risk project succeeds then the profit will fall to the shareholders, while the return to the creditor remains. But if the project fails then the creditor will incur losses. Increased return on investment and of course the greater the risk will benefit shareholders. On the contrary, high risk is not beneficial to creditors. To control it the creditor imposes higher interest to the company.

Aggressive Financial Reporting and Tax Reporting. The Company is a gathering place of interest from stakeholders who each have a different purpose. One of the stakeholders having an interest is the government in the tax framework. The Company has the possibility of engaging in various tax planning schemes to reduce tax liabilities (Balakrishnan et al, 2011).

There is no definition or size of tax aggressiveness that can be accepted thoroughly (Hanlon and Heizman, 2010). Some researchers and literature use different terms to describe corporate tax aggressiveness. Frank et al. (2009) defines tax aggressiveness as an act of manipulation to reduce taxable income through tax planning, whether related to tax evasion or not. Tax evasion is a barrier in tax collection so that State cash receipts are reduced. Balakrishnan, et al. (2011) states that companies that engage in tax aggressiveness may be characterized by lower transparency. The purpose of tax planning activities is to avoid paying taxes or making the tax burden to be lower.

There are various proxy measures of tax aggressiveness. But there is no proxy that captures perfectly the act of tax aggressiveness (Rego and Wilson, 2008). Proxy Effective Tax Rate (ETR) is the most widely used proxy in the literature. Crocker \& Slemrod (2004), Dyreng et al. (2008), as well as Lanis and Richardson (2012) using ETR as a proxy for measuring tax aggressiveness. A low ETR score can be an indicator of tax aggressiveness. Companies that avoid corporate taxes by reducing taxable income and keeping financial accounting earnings have a lower ETR score. In addition, the Book Tax Difference (BTD) proxy can be used as an alternative proxy for the measurement of tax aggressiveness. Book Tax Difference describes the difference between accounting profit and fiscal profit. The big difference between accounting earnings and taxable income in companies generally shows greater tax aggressiveness (Desai and Dharmapala, 2009).

Firm Value. The main goal of the company is to increase the value of the company through increasing shareholder wealth. The final goal to be achieved from the overall financial decision is to maximize shareholder wealth through the maximization of corporate value (Sartono, 2001: 6). The value of companies that go public is shown by the stock market price. If the stock market price increases the value of the firm increases as well. As for companies that do not go public, the value of a company can be measured at the selling price if the company is to be sold which not only reflects the value of the company's assets but includes the level of business risk, the prospect of the company, the management, the business environment and other factors (Sartono 2001: 12).

The market value of the stock is determined by the cash flow of the firm. Creating a positive cash flow can increase value. To increase the value of the company, the company 
has an interest in obtaining larger cash inflows. The value of the company consists of the value of debt and value of shares (Mamduh, 2004). Company value can be maximized if it is formed as a company for the following reasons (1) Limited liability reduces the risk borne by the investor. If other things are considered constant, the lower the risk of the company, the higher the value. (2) The value of a company depends on its growth opportunity, which in turn depends on the company's ability to gain capital. (3) The value of an asset depends on its liquidity, ie the ease of selling the asset and converting it into cash at "fair market value".

Brigham \& Houston (2008: 32) discloses factors affecting the firm's stock price. First, all financial assets are valued only to the extent to which they can generate cash flows. Second, the time of the cash flows, the faster the money is received the better because it can be reinvested. Third, investors usually dislike risks, so that if things are the same, they will pay more for a stock whose cash flows are relatively more certain than those whose cash flows are relatively riskier. Based on these three factors, managers can increase the value of the company by increasing the expected cash flow, accelerating its acceptance, and reducing the level of risk. The financial manager makes investment decisions and funding the company. The manager must determine the composition of debt and good equity through debt policy, and must decide the percentage of profit to be paid as dividend or retained and reinvested through dividend policy. Each of these investment and funding decisions will affect the level, timeliness, and risk level of the company's cash flow, and therefore will affect its share price as well.

\section{METHODS OF RESEARCH}

This research is an explanatory research with quantitative approach. The data used in this study is secondary data in the form of financial statements of manufacturing companies listed on the Indonesia Stock Exchange in 2005 to 2015. Research data were analyzed using multiple linear regressions after testing the classical assumption.

Tax aggressiveness is defined as an act of manipulation to decrease taxable income through tax planning, whether associated with tax evasion or not (Frank et al., 2009). This study uses Effective Tax Rates (ETR) as a measure of tax aggressiveness (Lanis and Richardson, 2012; Rusydi and Martani, 2014). ETR is calculated by:

$$
\text { ETR }=\frac{\text { Income Tax Expense }}{\text { Book Income }}
$$

ETR represents effective tax rate based on the amount of tax cash paid by the company in the current year. Income Tax Expense represents the amount of tax cash paid by company $i$ in year $t$ based on the company's financial statements. Book Income represents pre-tax income for firm i in year t based on company's financial statements.

The aggressiveness of financial reporting is shown by earnings management activities (Kamila and Martani, 2014). Measurement of aggressiveness of financial reporting is done using accrual (Decow et al, 1995 in Bergstresser and Philippon, 2006). Total accrual is calculated as follows.

$$
T A_{i, t}=\left(\Delta C A_{i, t}-\Delta C L_{i, t}-\Delta \operatorname{Cash}_{i, t}+\Delta S T D_{i, t}-\operatorname{Dep}_{i, t}\right) / A_{i, t-1}
$$

$\mathrm{Ta}_{i, t}$ represents the total accruals of firm i at time t. $\Delta C A_{i, t}$ represents change in current assets of firm $\mathrm{i}$ at time t. $\Delta C L_{i, t}$ represents change in current liabilities of firm $\mathrm{i}$ at time $\mathrm{t}$. $\Delta \operatorname{Cash}_{i, t}$ represents change in cash of firm i at time t. $\Delta S T D_{i, t}$ represents change in long term debt in current liabilities of firm i at time t. Dep $_{i, t}$ represents change in depreciation and amortization expenses of firm i at time t. $A_{i, t-1}$ is the lagged size (on assets) of firm i at time $\mathrm{t}-1$. 
Corporate value is defined as the perception of investors to the success of the company in managing its resources measured using the ratio of market to book value (Arifin, 2004).

$$
\text { Market to Book Value }=\frac{\text { market price per share }}{\text { bookvalue per share }}
$$

The equation model used to test the hypothesis is:

$$
M B V=\alpha_{0}+\beta_{1} E T R+\beta_{2} T A+\varepsilon_{1}
$$

Hypothesis 1 and 2 are accepted if $\beta_{1}$ and $\beta_{1}$ have probability values $<0.05(5 \%)$ or can be observed from the significance value $<0.05(5 \%)$. Hypothesis in this research formulated as follows:

$\mathrm{H}_{1}$ : tax reporting aggressiveness has an influence on firm value;

$\mathrm{H}_{2}$ : financial reporting aggressiveness has an influence on firm value.

\section{RESULTS OF STUDY}

Dyreng et al (2008) divide firm based on ETR into 3 groups: low ETR $(\leq 20 \%)$, mid ETR $(20 \%>$ ETR $\leq 40 \%)$ and high ETR ( > 40\%). Data on this research describe based on this category. Result shows that during 2005 until 2014, majority firm has mid ETR which is between $20 \%$ and $40 \%$. At 2015 the data show that majority firm is on low ETR condition. Descriptive analysis result shown below.

\begin{tabular}{|c|c|c|c|}
\hline & \multicolumn{3}{|c|}{ TAX GROUP } \\
\hline & Low & Mid & High \\
\hline Year & $n$ & $n$ & $n$ \\
\hline 2015 & 117 & 112 & 53 \\
\hline 2014 & 105 & 151 & 33 \\
\hline 2013 & 94 & 157 & 35 \\
\hline 2012 & 90 & 165 & 25 \\
\hline 2011 & 79 & 159 & 27 \\
\hline 2010 & 72 & 150 & 31 \\
\hline 2009 & 60 & 115 & 40 \\
\hline 2008 & 79 & 94 & 33 \\
\hline 2007 & 56 & 115 & 24 \\
\hline 2006 & 61 & 89 & 29 \\
\hline 2005 & 63 & 83 & 28 \\
\hline
\end{tabular}

Table 1 - ETR Descriptive

Classical assumption test includes normality test, multicolinearity test, heteroscedasticity test and autocorrelation test. Results of classical assumption shows that the data does not meet the normality assumption. The P-P chart shows residuals not spreading following diagonal lines. It means the regression equation does not satisfy the classical assumption of normality. To overcome this, the data is transformed into a natural logarithmic form.

The equation after being transformed into a natural logarithm becomes as follows:

$$
\text { LnMBV }=\alpha_{0}+\beta_{1} \text { LnETR }+\beta_{2} \text { LnTA }+\varepsilon_{1}
$$

Classical assumption test after the equation is transformed into natural logarithm shows that the regression equation model has fulfilled assumption of normality, heteroscedasticity, multicolinearity and autocorrelation. Therefore hypothesis testing can be done. The equation of the regression model that is formed is:

$$
\text { LgMBV }=-0.023 \operatorname{lgETR}-0.203 \lg T A
$$


Based on the equation, the effect of LGTA on IgMBV is -0.203 and the effect of IgETR on IgMBV is -0.023 . The negative regression coefficients for the two independent variables indicate that the increasing $\lg \mathrm{TA}$ and $\operatorname{lgETR}$ further decrease the IgMBV value. It means aggressiveness of financial reporting and aggressiveness of taxes has a negative relationship with the value of the company.

Table 2 - Hypothesis Testing

\begin{tabular}{ccc}
\hline Variables & Coefficient & Significance \\
\hline ETR & -0.023 & 0.722 \\
TA & -0.203 & 0.002 \\
\hline
\end{tabular}

The result of regression model test for hypothesis $1\left(\mathrm{H}_{1}\right)$ shows that $\lg T A$ effect on IgMBV has Sig value. 0.002. It means Sig. For testing $\mathrm{H}_{1}$ is smaller than the level of significance set at 0.05 so that $H_{1}$ is accepted and $H_{0}$ is rejected. The result is aggressiveness of financial reporting has significant negative effect to company value.

The result of regression model test for hypothesis $2\left(\mathrm{H}_{2}\right)$ shows that $\lg T A$ effect on $\operatorname{lgMBV}$ has Sig value. 0.722. It means Sig. For testing $\mathrm{H} 2$ is greater than the level of significance set at 0.05 so that $\mathrm{H}_{2}$ is rejected and $\mathrm{H}_{0}$ accepted. The result means that the tax aggressiveness has no significant effect on firm value.

\section{DISCUSSION OF RESULTS}

Hypothesis testing shows that the aggressiveness of financial statements has a significant negative effect on firm value. However, tax aggressiveness has no significant effect on firm value. This results shows that investors pay more attention to information about the aggressiveness of financial statements than information on tax aggressiveness.

The tax aggressiveness measured using tax evasion does not affect the firm's value. This finding is in line with Prasiwi (2015) that proves that tax evasion which is one form of tax aggressiveness has no significant effect on firm value. This shows that investors have not used information on tax aggressiveness in decision-making related to stock price assessment. In addition, tax aggressiveness can also be a form of aggressiveness of financial statements so that by taking into account the aggressiveness of financial statements includes tax aggressiveness.

\section{CONCLUSION}

The aggressiveness of financial statements influences investors' perceptions in assessing the company. The results show that the more companies do aggressive financial reporting, the investor will rate the company lower. The direction of the same relationship is also shown by the tax aggressiveness, but its influence proved to be insignificant. These results indicate that investors tend to use information aggressiveness of financial reporting as a basis for decision making. While tax aggressiveness does not affect the perception of investors directly in assessing the company.

\section{REFERENCES}

1. Arifin. 2004. Pengaruh Kepemilikan Manajerial dan Institusional terhadap Kebijakan Hutang, Kebijakan Hutang terhadap Nilai Perusahaan Serta Kepemilikan Manajerial dan Institusional terhadap Nilai Perusahaan yang Dimediasi oleh Kebijakan Hutang: Sebuah Perspektif Agency Theory (Studi Empiris Pada Perusahaan Real Estate and Properti di BEJ). Unpublished Thesis. Jurusan Akuntansi. Fakultas Ekonomi: Universitas Brawijaya.

2. Balakrishnan, K. Blouin, J. and Guay, W. 2011. Does Tax Aggressiveness Reduce Financial Reporting Transparency? University of Pennsylvania

3. Bergstresser, D. and Phillipon, T. 2006. CEO Incentives and Earning Management. Journal of Financial Economics 80 (2006) 511-529 
4. Brigham, E.F. and Houston, J.F. 2001. Manajemen Keuangan. Edisi kedelapan. Jakarta. Gelora Aksara Pratama.

5. Crocker, K.J. and Slemrod, J. 2004. Corporate Tax Evasion with Agency Costs. Pennsylvania State University

6. Dyreng, S.D., Hanlon, M., and Maydew, E.L. 2008. Long Run Corporate Tax Avoidance. The Accounting Review Vol. 83 No. 1 pp 61-82

7. Desai, M.A. and Dharmapala, D. 2009. Corporate Tax Avoidance and Firm Value. The Review of Economics and Statistics, August, 91(3): 537-546

8. Frank, M.M., Lynch, L.J., and Rego, S.O. 2009. Tax Reporting Aggressiveness and Its Relation to Aggressive Financial Reporting. The Accounting Review Vol 84 No 2 PP 467496

9. Ghozali, I. 2007. Aplikasi Analisis Multivariate dengan Program SPSS. Semarang: Badan Penerbit-Undip.

10. Hanafi, M.M. 2004. Manajemen Keuangan (Edisi 2004/2005). Yogyakarta: BPFE Yogyakarta

11. Heltzer, W., Mindak, M.P., and Shelton, S.W. 2012. The Relation Between Aggressive Financial Reporting and Aggressive Tax Reporting: Evidence From Ex-Arthur Andersen Clients. Research in Accounting Regulation.

12. Husnan, S. 1996. Dasar-Dasar Teori Portofolio. Yogyakarta: AMP YKPN

13. Jensen, M.C. and Meckling, W.H. 1976. Theory of The Firm: Managerial Behaviour, Agency Cost and Ownership Structure. Journal of Financial Economics 305-360

14. Lanis, R. and Richardson, G. 2012. Corporate Social Responsibility and Tax Aggressiveness: An Empirical Analysis. Journal Accounting and Public Policy.

15. Prasiwi, K.W. 2015. Pengaruh Penghindaran Pajak terhadap Nilai Perusahaan: Transparansi Informasi sebagai Variabel Pemoderasi. Unpublished Thesis. Universitas Diponegoro.

16. Rego, S.O. and Wilson, R. 2008. Executive Compensation, Tax Reporting Aggressiveness and Future Firm Performance. University of Lowa

17. Resmi, S. 2011. Perpajakan Teori and Kasus, Buku 1, edisi 6. Salemba Empat: Jakarta

18. Resmi, S. 2011. Perpajakan Teori and Kasus, Buku 2, edisi 6. Salemba Empat: Jakarta

19. Richardson, G., Taylor, G., and Lanis, R. 2013. The Impact of Board of Director Oversight Characteristics on Corporate Tax Aggressiveness: An Empirical Analysis. Journal Accounting and Public Policy.

20. Riyanto, B. 2001. Dasar-Dasar Pembelanjaan Perusahaan. Yogyakarta: Yayasan Badan Penerbit

21. Rusydi, M.K. and Martani, D. 2014. Pengaruh Struktur Kepemilikan terhadap Aggressive Tax Avoidance. National Symposium of Accounting 17, Mataram, Indonesia.

22. Sartono, R.A. 2001. Manajemen Keuangan. Yogyakarta: BPFE.

23. Sarunan, W.K. 2015. Pengaruh Modernisasi Sistem Administrasi Perpajakan terhadap Kepatuhan Wajib Pajak Orang Pribadi dan Wajib Pajak Badan pada kantor Pelayanan Pajak Pratama Manado. Jurnal EMBA, Vol. 3 No. 4 Desember 2015, Hal. 518-526

24. Sonnier, B.M.. Henig, C.J., Everett, J.O., Raabe, W.A. 2012. Reporting of Book-TaxDifferences for Financial and Tax Purpose: A Case Study. Journal of Accounting Education.

25. Suyanto, K.D. and Supramono. 2012. Likuiditas, Leverage, Komisaris Independen, dan Manajemen Laba terhadap Agresivitas Pajak Perusahaan. Jurnal Keuangan dan Perbankan.

26. Wahyuni, M.A. 2011. Tax Evasion: Dampak dari Self Assessment System. Universitas Pendidikan Ganesha. 